\title{
Dopamine Agonists Upregulate IL-6 and IL-8 Production in Human Keratinocytes
}

\author{
Andrea Cecilia Parrado Andrea Canellada Teresa Gentile \\ Estela Beatriz Rey-Roldán \\ Instituto de Estudios de la Inmunidad Humoral R.A. Margni (CONICET-UBA), Facultad de Farmacia y Bioquímica, \\ Universidad de Buenos Aires, Buenos Aires, Argentina
}

\section{Key Words}

Dopamine agonists $\cdot$ Cytokine $\cdot \mathrm{IL}-6 \cdot \mathrm{IL}-8 \cdot$ Keratinocyte cesses. These effects are mediated by dopaminergic and $\beta$ adrenergic receptors and by receptor-independent oxidative mechanisms.

Copyright $\odot 2012$ S. Karger AG, Basel

\begin{abstract}
Aim: Catecholamines regulate functions of the nervous, neuroendocrine and immune systems. Dopamine may modulate the activity of keratinocytes, which play a role in secreting cytokines and chemokines. The aim of this study was to evaluate the effect of dopaminergic agonists on the production of IL- 6 and IL- 8 by a non-tumoral human keratinocyte cell line (HaCaT). Methods: Cells were stimulated with dopamine and the $D_{2}$ dopamine receptor agonist cabergoline. Levels of IL- 6 and IL- 8 in culture supernatants were then determined. Cell proliferation was also assessed. Assays were carried out in the presence or absence of the dopaminergic and $\beta$-adrenergic receptor antagonists (sulpiride and propranolol, respectively) and ascorbic acid. Results: Dopamine stimulated the production of IL- 6 and IL- 8 in a concentrationdependent manner. The effects observed on the secretion of IL- 6 were more potent than those corresponding to IL-8 and were reduced by ascorbic acid. The dopamine-induced IL- 6 secretion was partially reduced by sulpiride and abrogated by propranolol. The latter drug was able to block the effect of dopamine on the secretion of IL-8. The cabergolineinduced IL- 6 release was reduced by sulpiride. Cell viability was not affected by any of the drugs. Conclusions: Dopaminergic agonists can stimulate keratinocytes to produce IL- 6 and IL-8 which are related to inflammatory cutaneous pro-
\end{abstract}

\section{Introduction}

Catecholamines (dopamine, adrenaline and noradrenaline) are known to regulate many functions of the central nervous system and the neuroendocrine axis. They also modulate functions of the immune system $[1,2]$. It is known that several immune cell types express neurotransmitter receptors $[3,4]$. Dopamine can modulate proliferation, differentiation, apoptosis and cytokine production by immune cells by means of its interaction with dopaminergic, $\alpha$ - and $\beta$-adrenergic receptors located on the cell surface and by intracellular oxidative mechanisms as well [4-6].

In the skin immune system, keratinocytes are connected with resident immune cells such as lymphocytes, Langerhans cells and macrophages, to contribute to innate immunity and inflammatory processes. Exposure to agents causing inflammation as well as environmental aggressors can induce the secretion of proinflammatory cytokines and chemokines (IL-1, IL-6, IL-8, IL-10, IL-18) by keratinocytes. These soluble mediators, in turn, carry out their functions in paracrine and autocrine manners $[7,8]$. The proinflammatory cytokine IL- 6 is known to be in-

\section{KARGER}

Fax +41613061234 E-Mail karger@karger.ch www.karger.com
(C) 2012 S. Karger AG, Basel

$1021-7401 / 12 / 0196-0359 \$ 38.00 / 0$

Accessible online at:

www.karger.com/nim
Dr. Estela Beatriz Rey-Roldán

Cátedra de Inmunología, Facultad de Farmacia y Bioquímica

Universidad de Buenos Aires

Junín $9564^{\circ}$ piso, Buenos Aires 1113 (Argentina)

E-Mail estelar@ffyb.uba.ar 
volved in the proliferation and differentiation of epidermal cells [9]. Modifications in the regulatory pathways of IL- 6 are related to abnormal inflammatory and proliferative processes, such as keloid formation during the wound healing process [10]. The main function of IL- 8 is to stimulate the chemotaxis of neutrophils which secrete antimicrobial peptides, i.e. defensin and cathelicidin, which play a crucial role in defense mechanisms of the skin [7]. The latter chemokine is also implicated in proliferation and chemotaxis of keratinocytes [11]. Moreover, several studies have demonstrated that keratinocytes belonging to psoriasic patients secrete high levels of IL-8 [12].

The ability of keratinocytes to synthesize and degrade catecholamines, as well as their capacity to express dopaminergic and $\alpha / \beta$-adrenergic receptors on their surface, has been demonstrated [13-15]. These receptors have been proven to be implicated in the pathogeny of skin inflammatory diseases such as vitiligo, psoriasis and atopic dermatitis $[13,16]$ and in the regulation of wound healing [17-19]. However, the participation of the dopaminergic pathways in the physiology of the skin immune system has not been studied so far.

Catecholamines can modulate the immune function through oxidative processes in addition to its interaction with catecholaminergic receptors. Keratinocytes have many antioxidant systems (enzymes and molecules such as tocopherol, glutathione and ascorbic acid) which protect cells from oxidative damages generated by environmental factors [20]. In the HaCaT human keratinocyte cell line, the presence of efficient systems for the intracellular accumulation of ascorbic acid have been demonstrated [21]. This non-tumoral cell line is an excellent model to perform studies under physiological conditions, since these cells have phenotypical features that are similar to those of normal keratinocytes $[22,23]$. Since studies dealing with the research of dopaminergic pathways operating in the skin immune system are scarce, the aim of the present work was to evaluate the effect of dopamine and the dopaminergic agonist cabergoline in the regulation of IL- 6 and IL- 8 production. Further, in order to assess whether the effect was mediated by dopaminergic/ $\beta$-adrenergic receptors or oxidative mechanisms, we used catecholaminergic receptor antagonists as well as ascorbic acid as antioxidant.

\section{Materials and Methods}

\section{Chemicals}

Dopamine (Sigma, St. Louis, Mo., USA), the $\beta$-adrenergic antagonist propranolol (Imperial Chemical, England), the dopaminergic antagonists haloperidol (Sigma) and sulpiride (Vipral,
Laboratorio IVAX Argentina, SA) were dissolved in $0.1 \mathrm{~N}$ acetic acid. Cabergoline (kindly provided by Laboratorios Beta, Argentina) is a $\mathrm{D}_{2}$-type dopaminergic agonist displaying low affinity for adrenergic receptors. This drug was dissolved in absolute ethanol plus $10 \%$ phosphate-buffered saline. Work dilutions were done in RPMI medium supplemented with fetal calf serum, $100 \mathrm{IU} / \mathrm{ml}$ penicillin, $100 \mu \mathrm{g} / \mathrm{ml}$ streptomycin, $2 \mathrm{mM}$ pyruvate and $2 \mathrm{mM}$ glutamine (Gibco-BRL/Invitrogen, Argentina).

\section{Cell Culture}

$\mathrm{HaCaT}$ cells, a non-tumoral human epithelial keratinocyte cell line, were kindly provided by Prof. N.E. Fusening from the German Cancer Research Center (Heidelberg, Germany). Cells were cultured in RPMI-1640 medium supplemented with $10 \% \mathrm{fe}-$ tal calf serum, penicillin, streptomycin, pyruvate and glutamine at $37^{\circ} \mathrm{C}$ under a $5 \% \mathrm{CO}_{2}$ atmosphere until confluence was reached.

\section{Treatment}

Keratinocytes $\left(1 \times 10^{4}\right.$ cells/well $)$ were placed in 96-well microtiter plates and stimulated with different concentrations of dopaminergic agonists (dopamine $10^{-4}$ to $10^{-7} \mathrm{M}$, cabergoline $10^{-4}$ and $10^{-5} \mathrm{M}$ ) in the presence or absence of $0.1 \mathrm{mM}$ ascorbic acid and in the presence or absence of dopaminergic (haloperidol, sulpiride at $10^{-5}$ and $10^{-4} \mathrm{M}$ ) and $\beta$-adrenergic (propranolol $10^{-5} \mathrm{M}$ ) antagonists and incubated for $24 \mathrm{~h}$. Antagonists were added $1 \mathrm{~h}$ previous to the stimulation with dopamine or cabergoline. At the end of the incubation time, the supernatants were collected and kept at $-40^{\circ} \mathrm{C}$ for subsequent determination of cytokine levels. Experiments were repeated $4-5$ times each.

\section{Cell Proliferation and Viability}

The WST-1 tetrazolium salt was employed (Roche Applied Science, Argentina). Upon oxidation by the mitochondrial system, the color developed by this reagent is a measure of the proliferation index of cells. Briefly, after $24 \mathrm{~h}$ of culture, the salt was added and incubated at $37^{\circ} \mathrm{C}$ with a $5 \% \mathrm{CO}_{2}$ atmosphere for $1 \mathrm{~h}$. The formazan produced upon cleavage of the salt was quantified in an ELISA reader (Meterterch $\Sigma 960)$ at $450 \mathrm{~nm}\left(\mathrm{OD}_{450}\right)$. The values plotted are the means \pm SEM of the optical density $\left(\mathrm{OD}_{450}\right)$ obtained from $4-5$ independent experiments.

\section{Cytokine Determination}

Cytokine levels were determined in culture supernatants by capture ELISA employing commercial kits (R\&D Systems for human IL-6, and BD OptEIA, Bioscience, for human IL-8), according to the manufacturer's directions. ODs were measured in an ELISA reader (Meterterch $\Sigma 960$ ). Cytokine concentrations were derived from standard curves. Detection limits were 2.3 and 4.0 $\mathrm{pg} / \mathrm{ml}$ for IL- 6 and IL- 8 , respectively. The values plotted are the means \pm SEM of the percentage values obtained from 4-5 independent experiments (considering the control value as 100\%).

\section{Statistical Analysis}

The effect of dopaminergic agonists on the production of cytokines and on proliferation was analyzed by two-way analysis of variance (ANOVA) followed by Bonferroni's a posteriori test. The effect of antagonists on the dopaminergic agonist-induced cytokine release was analyzed by one-way ANOVA followed by the a posteriori Student-Newman-Keuls test. A p value of $<0.05$ was considered significant. 


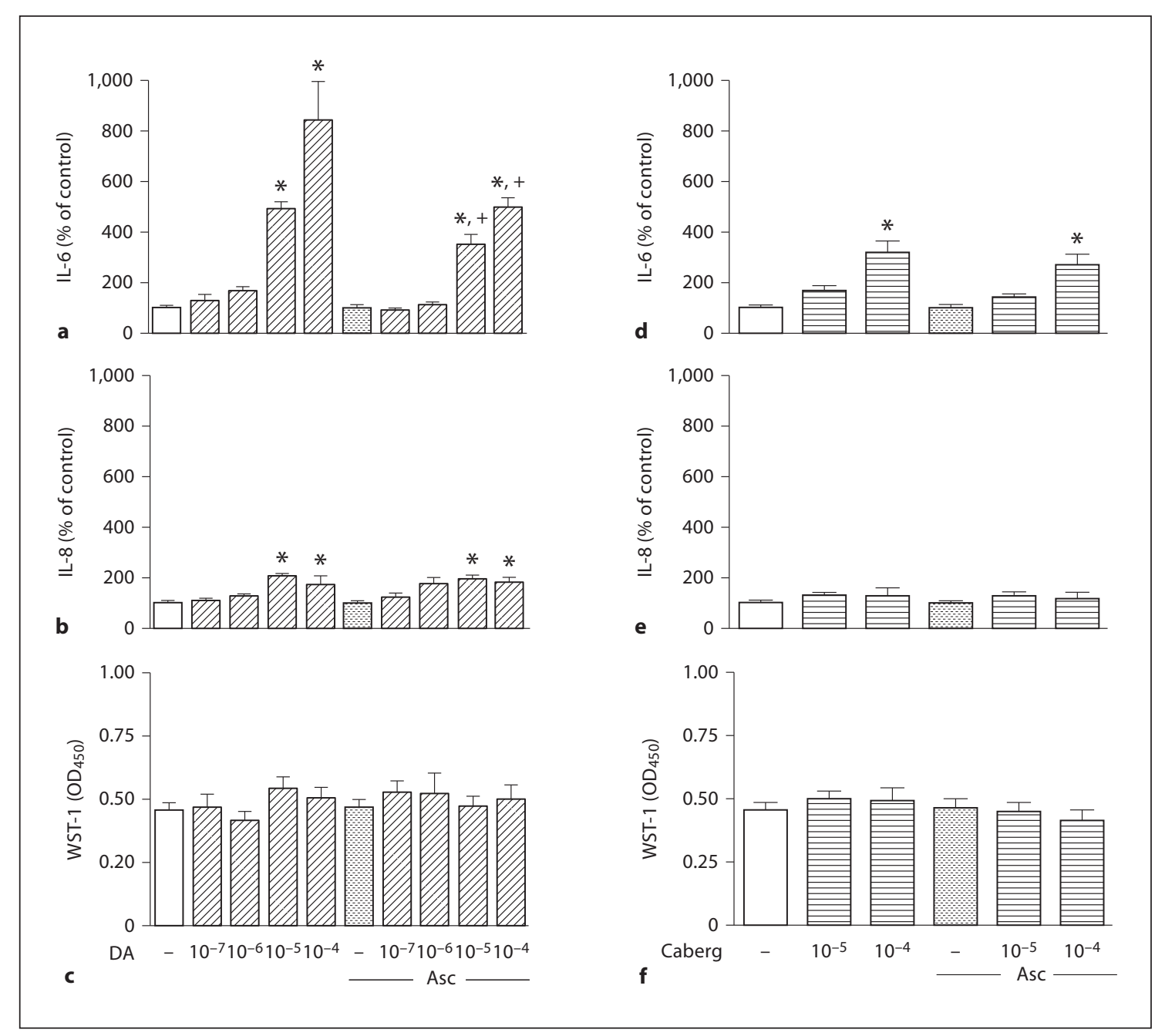

Fig. 1. Effect of the dopaminergic agonists dopamine (DA) and cabergoline (Caberg) on the secretion of cytokines and cell viability measured by WST-1 tetrazolium salt assay. Secretion of IL-6 (a, d), IL-8 (b, e) and cell viability (c, f) by HaCaT cells after $24 \mathrm{~h}$ of culture in the absence (RPMI) or presence of $0.1 \mathrm{mM}$ ascorbic acid (Asc). Cytokine levels were expressed as percentage of control (which was assigned a value of $100 \%) \pm$ SEM. Cell viability was expressed as the average $\mathrm{OD}_{450} \pm$ SEM. ${ }^{*} \mathrm{p}<0.05$ versus control; ${ }^{+} \mathrm{p}<0.05$ versus dopamine.

\section{Results}

Effect of Dopaminergic Agonists on the Production of Cytokines by $\mathrm{HaCaT}$ Cells

In order to evaluate the effect of dopaminergic agonists on the production of IL- 6 and IL-8, keratinocytes were stimulated with different concentrations of dopamine $\left(10^{-7}\right.$ to $\left.10^{-4} \mathrm{M}\right)$ and cabergoline $\left(10^{-5}\right.$ and $\left.10^{-4} \mathrm{M}\right)$ for $24 \mathrm{~h}$.

Levels of IL-6 in culture supernatants increased after stimulation with dopamine in a dose-dependent manner, reaching significant levels for $10^{-5}$ and $10^{-4} \mathrm{M}$ dopamine (fig. 1a). The latter effect was reduced by the addition of $0.1 \mathrm{mM}$ ascorbic acid. There were no significant differences between control levels of IL- 6 in the presence or absence of ascorbic acid $(23.83 \pm 1.49$ and $34.07 \pm 3.69$ $\mathrm{pg} / \mathrm{ml}$, respectively).

Levels of IL-8 in culture supernatants of HaCaT cells were also increased in response to the stimulation with $10^{-5}$ and $10^{-4} \mathrm{M}$ dopamine. Although this increase was less pronounced than the one obtained for IL-6, IL-8 reached levels that doubled those of controls. Besides, the increase in IL- 8 was not reduced by the addition of ascorbic acid (fig. 1b). Again, no differences were found be- 

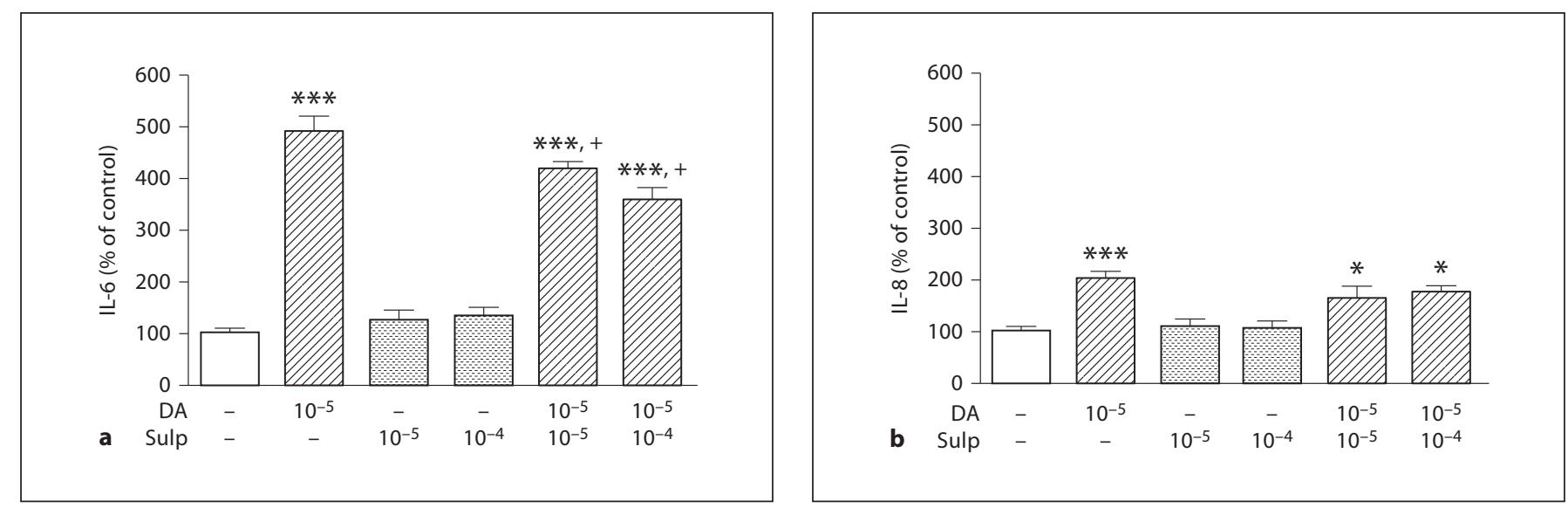

Fig. 2. Effect of the dopaminergic antagonist sulpiride (Sulp) on the production of IL-6 (a) and IL-8 (b) after treatment of HaCaT cells with dopamine (DA). Data are expressed as percentage of control values \pm SEM. ${ }^{*} \mathrm{p}<0.05$ versus control; ${ }^{* * *} \mathrm{p}<0.001$ versus control; ${ }^{+} \mathrm{p}<0.05$ versus dopamine.

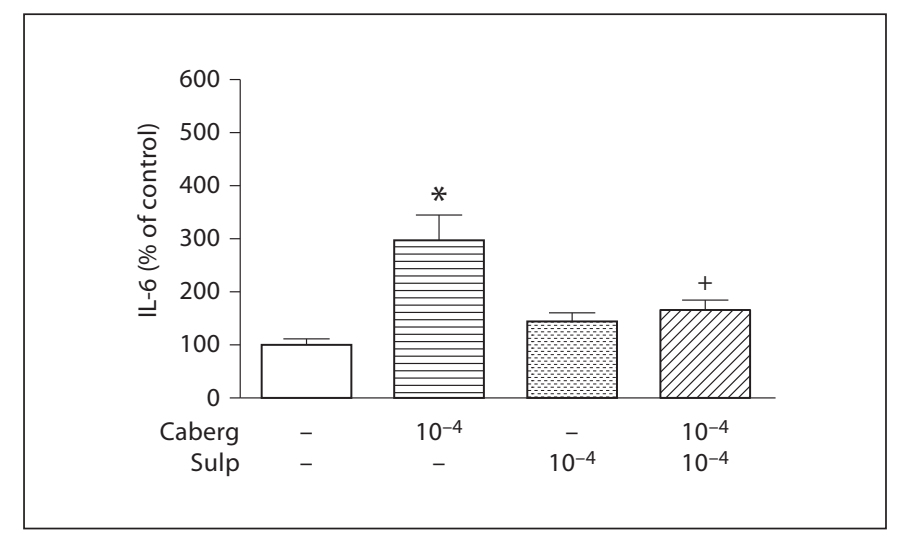

Fig. 3. Effect of the dopaminergic antagonist sulpiride (Sulp) on the production of IL- 6 after treatment of HaCaT cells with cabergoline (Caberg). Data are expressed as percentage of control values \pm SEM. ${ }^{*} \mathrm{p}<0.05$ versus control; ${ }^{+} \mathrm{p}<0.05$ versus cabergoline.

tween basal levels of this cytokine in the presence or absence of ascorbic acid $(69.02 \pm 4.36$ and $78.28 \pm 3.66 \mathrm{pg} /$ $\mathrm{ml}$, respectively).

At the concentrations employed, dopamine did not modify cell viability, as assessed by WST-1 (fig. 1c).

In order to evaluate the role of $\mathrm{D}_{2}$ receptors in cytokine production, cabergoline was employed, since this drug displays high affinity for these receptors. Upon stimulation of HaCaT cells with $10^{-5}$ and $10^{-4} \mathrm{M}$ cabergoline, a dose-dependent increase in the release of IL-6 was observed. Values were significantly different from controls when $10^{-4} \mathrm{M}$ cabergoline was employed; however, the maximum effect obtained was lower than that obtained with dopamine (fig. 1d). No significant increase in the production of IL-8 was observed after stimulation with the same dopaminergic agonist (fig. 1e). The addition of ascorbic acid did not modify the cytokine secretion profile after cabergoline stimulation (fig. 1d, e). Furthermore, at the concentrations of cabergoline employed, cell viability was not affected (fig. 1f).

\section{Effect of the Dopaminergic Antagonist Sulpiride on the Dopaminergic Agonist-Induced IL-6 and IL-8}

Secretion

In order to determine the type of receptor involved in the production of cytokines induced by dopaminergic agonists, the $\mathrm{D}_{2}$ antagonist sulpiride was employed. Unlike haloperidol $\left(10^{-4} \mathrm{M}\right)$ which induced a decrease in cell viability (data not shown), the addition of sulpiride at $10^{-5}$ and $10^{-4} \mathrm{M}$ did not have toxic effects on $\mathrm{HaCaT}$ cells.

As shown in figure $2 \mathrm{a}$, the addition of the antagonist sulpiride $10^{-5}$ and $10^{-4} \mathrm{M}$ induced a low but significant decrease in the production of IL- 6 when keratinocytes were stimulated with dopamine at $10^{-5} \mathrm{M}$ in the absence of ascorbic acid, a condition under which the maximum cytokine release was obtained. On the other hand, the receptor blockade induced by sulpiride did not affect the dopamine-induced secretion of IL-8 (fig. 2b). As expected, the addition of sulpiride at $10^{-4} \mathrm{M}$ induced a significant decrease in the cabergoline-induced secretion of IL-6 (fig. 3). 

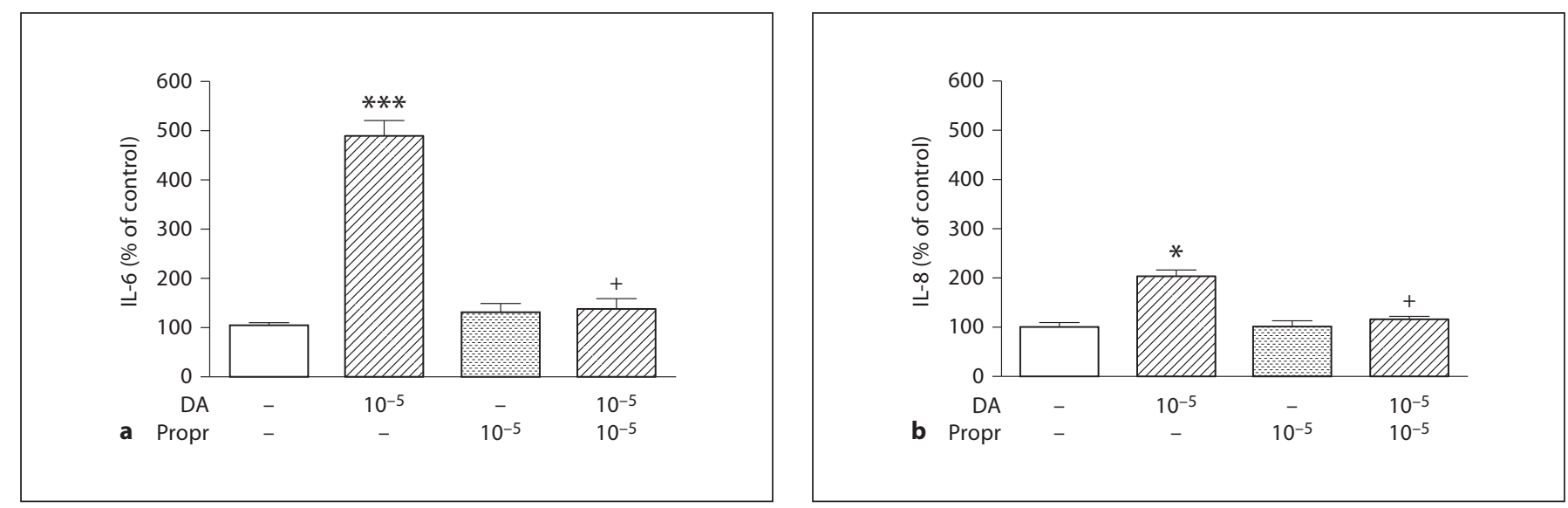

Fig. 4. Effect of the $\beta$-adrenergic antagonist propranolol (Propr) on the production of IL-6 (a) and IL-8 (b) after the treatment of HaCaT cells with dopamine (DA). Data are expressed as percentage of control values \pm SEM. ${ }^{*} \mathrm{p}<0.05$ versus control; ${ }^{* *} \mathrm{p}<0.001$ versus control; ${ }^{+} \mathrm{p}<0.05$ versus dopamine.

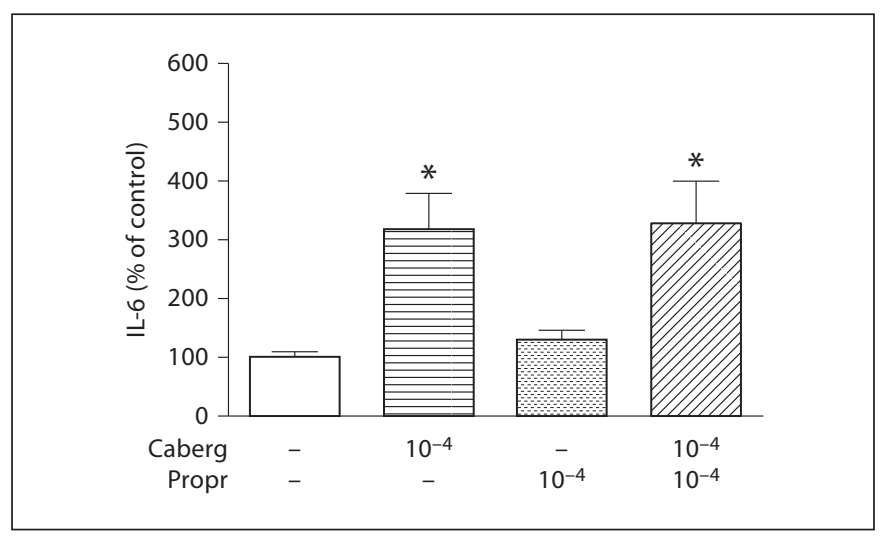

Fig. 5. Effect of the $\beta$-adrenergic antagonist propranolol (Propr) on the production of IL- 6 after treatment with cabergoline (Caberg). Data are expressed as percentage of control values \pm SEM. ${ }^{*} \mathrm{p}<0.05$ versus control.

Effect of the $\beta$-Adrenergic Antagonist Propranolol on the Dopaminergic Agonist-Induced Production of IL-6 and $I L-8$

In order to determine whether the effect of the dopaminergic agonists on the production of cytokines was also mediated by $\beta$-adrenergic receptors, as described for cells of the immune system [24], keratinocytes were treated with propranolol, a selective $\beta$-adrenergic blocker. At $10^{-5} \mathrm{M}$, this antagonist was able to diminish significantly the stimulatory effect exerted by dopamine on the release of IL-6 and IL-8 (fig. 4). As expected, the addition of
$10^{-4} \mathrm{M}$ propranolol did not modify the stimulatory effect of cabergoline, which has a low affinity for $\beta$-adrenergic receptors, as regards the production of IL-6 (fig. 5).

In the absence of dopaminergic agonists, at the concentrations employed, propranolol did not modify the levels of cytokines released.

\section{Discussion}

In this study, we have demonstrated that dopaminergic agonists can stimulate keratinocytes to produce IL-6 and IL- 8 . This effect is mediated by $\beta$-adrenergic and dopaminergic receptors, together with the intervention of receptor-independent oxidative mechanisms.

The modulatory effect of catecholamines on the function of several cells of the immune system is well known $[3,4,25]$. It has recently been demonstrated that both epinephrine and norepinephrine can stimulate the production of proinflammatory cytokines [tumor necrosis factor- $\alpha$ (TNF- $\alpha$ ), IL-1 $\beta$ and IL-6] by macrophages which become activated by these catecholamines [26]. At the epidermal level, transformed cells like melanoma, can produce IL-6, IL-8 and vascular endothelial growth factor upon stimulation with norepinephrine, and the latter phenomenon is in association with cancer progression [27]. Our results demonstrated that dopamine can stimulate the production of IL- 6 and IL- 8 by the HaCaT keratinocyte cell line. It is noteworthy that the effect on the production of IL- 6 was greater than that observed for IL- 
8. In line with our results, it has also been demonstrated that dopamine has a stimulatory effect, inducing adrenal cells to secrete IL-6 [28], and that lung endothelial cells produce IL-8 upon stimulation [29].

The stimulatory effect on the production of IL- 6 exerted by dopamine in keratinocytes was less marked in the presence of ascorbic acid. The latter phenomenon was not observed for IL-8. It is known that in this cell type, vitamin $\mathrm{C}$ contributes to counteract the oxidative stress [20] and diminishes the production of IL- 6 induced by the exposure to UVA light [30].

Similarly to our observations, in monocytes obtained from adults, vitamin $\mathrm{C}$ decreases the production of the proinflammatory cytokines IL- 6 and TNF- $\alpha$ without affecting the secretion of IL-8 [31]. However, these authors found opposite effects in blood cells of neonates induced by ascorbic acid [32], thus evidencing a differential modulatory effect of vitamin $\mathrm{C}$ on cytokine production. In agreement with these observations and employing UVB light as inflammatory stimulus, Kang et al. [33] have demonstrated that $2.5 \mathrm{~mm}$ ascorbic acid (a concentration higher than that employed in our study) can abrogate the increase in IL-8 and monocyte chemotactic protein-1 induced by suppression of the p38 MAPK pathway, thus regulating the inflammatory response. Although Beck et al. [29] have demonstrated in lung endothelial cells that vitamin $\mathrm{C}$ and other antioxidants can suppress the stimulatory effect of dopamine on the production of IL-8, a concentration similar to that employed in our study $(0.1$ $\mathrm{mM}$ ) did not have any effect.

Our results suggest that the effect of dopamine on the production of IL- 6 is mediated, at least in part, by oxidative mechanisms. The production of IL-8, on the contrary, is governed by less sensitive redox pathways.

High concentrations of dopamine have been proven to exert antiproliferative effects. These effects are mediated by dopaminergic receptors in lymphocytes [3] and by oxidative pathways in macrophages [34]. Our studies showed that the increase in the levels of IL- 6 and IL- 8 after the stimulation with dopaminergic agonists is not a consequence of changes in keratinocyte viability.

The behavior of cabergoline was different. This drug is a potent $\mathrm{D}_{2}$ agonist employed in the treatment of hyperprolactinemia due to hypofiseal tumors and, at a lesser extent, in Parkinson's disease. This ergot derivative increased the production of IL- 6 by keratinocytes without affecting cell viability. The effect was not modified by the presence of ascorbic acid. It has been suggested that cabergoline has antioxidant properties in the central nervous system which could act synergistically with endogenous antioxidants such as vitamin E and ascorbic acid [35-37]. In the cell line employed herein, a synergistic effect of this drug with ascorbic acid was not observed, as regards the production of IL-6. The latter results could be due to a low concentration of the antioxidant employed $(0.1 \mathrm{mM})$ and due to the model used to assess the effect of this dopaminergic agonist. The production of IL- 8 was not affected by the presence of cabergoline. This is the first work dealing with the effect of cabergoline on the production of cytokines at the skin cell level.

From the results obtained in this work, it could be suggested that the effect of dopamine on the production of IL- 6 by keratinocytes might be mediated by oxidative mechanisms triggered by the amine itself. This would not be the case for the production of IL-8. Other works have demonstrated that dopamine regulates the production of IL-12p 40 and IL-10 by macrophages by both receptor-dependent and receptor-independent mechanisms, the latter ones being related to the autooxidation processes [24].

It is known that dopaminergic agonists can either induce or suppress the production of several cytokines, depending on the cell type, the mechanism involved and the physiological status $[38,39]$. It has been suggested that dopaminergic agonists exert their effects through the binding to dopaminergic receptors when used at low concentrations, whereas when high doses are used, their effects are manifested through the binding to adrenergic receptors. Although the participation of catecholaminergic receptors in the modulatory effects of dopamine has been demonstrated in many cell types $[3,40]$, the receptor subtypes involved in the production of cytokines are still a matter of controversy. Our work demonstrated that, apart from the oxidative mechanisms present in keratinocytes, dopamine can stimulate the production of IL- 6 by means of its interaction with dopaminergic and $\beta$-adrenergic receptors. Sulpiride, a $\mathrm{D}_{2}$ antagonist, partially decreased the dopamine-induced production of IL-6 and, as expected, this drug suppressed the response induced by cabergoline, a potent $\mathrm{D}_{2}$ agonist. This effect was not due to a toxic effect of sulpiride on keratinocytes, since no alterations in cell viability were detected. In line with our results, it has been demonstrated that in cells from the adrenal zona glomerulosa, dopamine can increase the $\mathrm{D}_{2}$ receptor-mediated release of IL- 6 and it can also suppress the production of TNF- $\alpha$ [28]. Haskó et al. [24] have observed that dopamine suppresses the production of IL-12 in macrophages and that this effect is mediated by $\beta$-adrenergic receptors. The observations made by these authors highlight an important modulatory role of dopamine in inflammation and during the immune 
response. In our study, it was demonstrated that propranolol, a $\beta$-adrenergic antagonist, blocked the stimulatory effect of dopamine on the production of both IL- 6 and IL-8. These results indicate that $\beta$-adrenergic receptors would also be involved in the effect of dopamine on keratinocytes.

It is known that IL- 6 and IL-8 stimulate the proliferation of human keratinocytes and their overexpression is related to inflammatory and hyperproliferative disorders of the skin $[9,11,12,41]$. Furthermore, dopaminergic and adrenergic receptors are known to be involved in the skin healing processes $[17,42]$. IL- 6 has also been demonstrated to be a potent mediator that facilitates wound healing of the corneous epithelium [43], and therefore, it could be hypothesized that dopamine could induce these effects through the induction of IL-6 secretion. However, this requires additional in vivo studies.
In summary, our results evidenced a modulatory role of dopaminergic agonists in keratinocyte functionality, affecting the production of proinflammatory cytokines or chemokines. The effect of dopamine at the cutaneous level should be borne in mind upon administration of dopamine agonists to treat neurological and neuroendocrine disorders.

\section{Acknowledgment}

This work was supported by grants from the University of Buenos Aires and CONICET (National Research Council of Argentina). The authors wish to thank Dr. Guillermo G. Nuñez for his assistance in the translation of the manuscript.

\section{References}

1 Besedovsky HO, Rey AD: Physiology of psychoneuroimmunology: a personal view. Brain Behav Immun 2007;21:34-44.

-2 Elenkov IJ, Wilder RL, Chrousos GP, Vizi ES: The sympathetic nerve - an integrative interface between two supersystems: the brain and the immune system. Pharmacol Rev 2000;52:595-638.

3 Oberbeck R: Catecholamines: physiological immunomodulators during health and illness. Curr Med Chem 2006;13:1979-1989.

4 Jiang JL, Qiu YH, Peng YP, Wang JJ: Immunoregulatory role of endogenous catecholamines synthesized by immune cells. Sheng Li Xue Bao 2006;58:309-317.

-5 Sarkar C, Basu B, Chakroborty D, Dasgupta PS, Basu S: The immunoregulatory role of dopamine: an update. Brain Behav Immun 2010;24:525-528.

6 Pacheco R, Prado CE, Barrientos MJ, Bernales S: Role of dopamine in the physiology of T-cells and dendritic cells. J Neuroimmunol 2009;216:8-19.

7 Nestle FO, Di Meglio P, Qin JZ, Nickoloff BJ: Skin immune sentinels in health and disease. Nat Rev Immunol 2009;9:679-691.

-8 Suter MM, Schulze K, Bergman W, Welle M, Roosje P, Muller EJ: The keratinocyte in epidermal renewal and defence. Vet Dermatol 2009;20:515-532.

-9 Hernandez-Quintero M, Kuri-Harcuch W, Gonzalez Robles A, Castro-Munozledo F: Interleukin-6 promotes human epidermal keratinocyte proliferation and keratin cytoskeleton reorganization in culture. Cell Tissue Res 2006;325:77-90.
10 Ghazizadeh M: Essential role of IL-6 signaling pathway in keloid pathogenesis. J Nihon Med Sch 2007;74:11-22.

-11 Kulke R, Bornscheuer E, Schluter C, Bartels J, Rowert J, Sticherling M, Christophers E: The CXC receptor 2 is overexpressed in psoriatic epidermis. J Invest Dermatol 1998;110: 90-94

12 Pietrzak AT, Zalewska A, Chodorowska G, Krasowska D, Michalak-Stoma A, Nockowski P, Osemlak P, Paszkowski T, Rolinski JM: Cytokines and anticytokines in psoriasis. Clin Chim Acta 2008;394:7-21.

13 Grando SA, Pittelkow MR, Schallreuter KU: Adrenergic and cholinergic control in the biology of epidermis: physiological and clinical significance. J Invest Dermatol 2006;126: 1948-1965.

- 14 Fuziwara S, Suzuki A, Inoue K, Denda M Dopamine $\mathrm{D}_{2}$-like receptor agonists accelerate barrier repair and inhibit the epidermal hyperplasia induced by barrier disruption. J Invest Dermatol 2005; 125:783-789.

15 Brenci S, Rialdi V, Rialdi G: Neuroimmunological activities of keratinocytes. International Electronic Journal on Dermopharmacological Research 2001 (articles 2001):1-6. http://www.vevy.com/relata.

16 Sivamani RK, Lam ST, Isseroff RR: Beta adrenergic receptors in keratinocytes. Dermatol Clin 2007;25:643-653.

17 Shome S, Rana T, Ganguly S, Basu B, Chaki Choudhury S, Sarkar C, Chakroborty D, Dasgupta PS, Basu S: Dopamine regulates angiogenesis in normal dermal wound tis sues. PLoS One 2011;6:e25215.
18 Sivamani RK, Pullar CE, Manabat-Hidalgo CG, Rocke DM, Carlsen RC, Greenhalgh DG, Isseroff RR: Stress-mediated increases in systemic and local epinephrine impair skin wound healing: potential new indication for beta blockers. PLoS Med 2009;6:e12.

19 Pullar CE, Manabat-Hidalgo CG, Bolaji RS, Isseroff RR: Beta-adrenergic receptor modulation of wound repair. Pharmacol Res 2008; 58:158-164

20 Catani MV, Savini I, Rossi A, Melino G, Avigliano L: Biological role of vitamin C in keratinocytes. Nutr Rev 2005;63:81-90.

21 Savini I, Duflot S, Avigliano L: Dehydroascorbic acid uptake in a human keratinocyte cell line (HaCaT) is glutathione-independent. Biochem J 2000;345:665-672.

-22 Boukamp P, Petrussevska RT, Breitkreutz D, Hornung J, Markham A, Fusenig NE: Normal keratinization in a spontaneously immortalized aneuploid human keratinocyte cell line. J Cell Biol 1988;106:761-771.

-23 Yoshizumi M, Nakamura T, Kato M, Ishioka T, Kozawa K, Wakamatsu K, Kimura H: Release of cytokines/chemokines and cell death in UVB-irradiated human keratinocytes, HaCaT. Cell Biol Int 2008;32:1405-1411.

$>24$ Haskó G, Szabo C, Nemeth ZH, Deitch EA: Dopamine suppresses IL-12 p40 production by lipopolysaccharide-stimulated macrophages via a beta-adrenoceptor-mediated mechanism. J Neuroimmunol 2002;122:3439.

25 Leposavic G, Pilipovic I, Radojevic K, Pesic V, Perisic M, Kosec D: Catecholamines as immunomodulators: a role for adrenoceptor-mediated mechanisms in fine tuning of T-cell development. Auton Neurosci 2008;144:1-12. 
-26 Flierl MA, Rittirsch D, Nadeau BA, Sarma JV, Day DE, Lentsch AB, Huber-Lang MS, Ward PA: Upregulation of phagocyte-derived catecholamines augments the acute inflammatory response. PLoS One 2009; 4:e4414.

-27 Yang EV, Kim SJ, Donovan EL, Chen M, Gross AC, Webster Marketon JI, Barsky $\mathrm{SH}$, Glaser R: Norepinephrine upregulates VEGF, IL-8, and IL-6 expression in human melanoma tumor cell lines: implications for stress-related enhancement of tumor progression. Brain Behav Immun 2009;23:267275.

-28 Ritchie PK, Ashby M, Knight HH, Judd AM: Dopamine increases interleukin 6 release and inhibits tumor necrosis factor release from rat adrenal zona glomerulosa cells in vitro. Eur J Endocrinol 1996;134:610-616.

-29 Beck GC, Oberacker R, Kapper S, von Zabern D, Schulte J, van Ackern K, van der Woude FJ, Yard BA: Modulation of chemokine production in lung microvascular endothelial cells by dopamine is mediated via an oxidative mechanism. Am J Respir Cell Mol Biol 2001;25:636-643.

-30 Tebbe B, Wu S, Geilen CC, Eberle J, Kodelja $\mathrm{V}$, Orfanos CE: L-Ascorbic acid inhibits UVA-induced lipid peroxidation and secretion of IL-1alpha and IL-6 in cultured human keratinocytes in vitro. J Invest Dermatol 1997;108:302-306.
31 Hartel C, Strunk T, Bucsky P, Schultz C: Effects of vitamin $\mathrm{C}$ on intracytoplasmic cytokine production in human whole blood monocytes and lymphocytes. Cytokine 2004; 27:101-106.

32 Hartel C, Puzik A, Gopel W, Temming P, Bucsky P, Schultz C: Immunomodulatory effect of vitamin $\mathrm{C}$ on intracytoplasmic cyto kine production in neonatal cord blood cells Neonatology 2007;91:54-60.

33 Kang JS, Kim HN, Jung da J, Kim JE, Mun GH, Kim YS, Cho D, Shin DH, Hwang YI, Lee WJ: Regulation of UVB-induced IL-8 and MCP-1 production in skin keratinocytes by increasing vitamin $\mathrm{C}$ uptake via the redistribution of SVCT-1 from the cytosol to the membrane. J Invest Dermatol 2007;127:698706.

-34 Brown SW, Meyers RT, Brennan KM, Rumble JM, Narasimhachari N, Perozzi EF, Ryan JJ, Stewart JK, Fischer-Stenger K: Catecholamines in a macrophage cell line. J Neuroimmunol 2003;135:47-55.

35 Lombardi G, Varsaldi F, Miglio G, Papini MG, Battaglia A, Canonico PL: Cabergoline prevents necrotic neuronal death in an in vitro model of oxidative stress. Eur J Pharmacol 2002;457:95-98.

36 Yoshida T, Tanaka M, Suzuki Y, Sohmiya M, Okamoto K: Antioxidant properties of cabergoline: inhibition of brain auto-oxidation and superoxide anion production of microglial cells in rats. Neurosci Lett 2002;330:1-4.
37 Sohmiya M, Tanaka M, Okamoto K, Fujisawa A, Yamamoto Y: Synergistic inhibition of lipid peroxidation by vitamin $\mathrm{E}$ and A dopamine agonist, cabergoline. Neurol Res 2004; 26:418-421.

38 Beck G, Brinkkoetter P, Hanusch C, Schulte J, van Ackern K, van der Woude FJ, Yard BA: Clinical review: immunomodulatory effects of dopamine in general inflammation. Crit Care 2004;8:485-491.

39 Bergmann M, Sautner T: Immunomodulatory effects of vasoactive catecholamines. Wien Klin Wochenschr 2002;114:752-761.

40 Basu S, Dasgupta PS: Dopamine, a neurotransmitter, influences the immune system. J Neuroimmunol 2000;102:113-124.

41 Grossman RM, Krueger J, Yourish D, Granelli-Piperno A, Murphy DP, May LT, Kupper TS, Sehgal PB, Gottlieb AB: Interleukin 6 is expressed in high levels in psoriatic skin and stimulates proliferation of cultured human keratinocytes. Proc Natl Acad Sci USA 1989;86:6367-6371.

42 Pullar CE, Grahn JC, Liu W, Isseroff RR: Beta2-adrenergic receptor activation delays wound healing. FASEB J 2006;20:76-86.

$\checkmark 43$ Nishida T, Nakamura M, Mishima H, Otori T, Hikida M: Interleukin 6 facilitates corneal epithelial wound closure in vivo. Arch Ophthalmol 1992;110:1292-1294. 